\title{
David Oliver: The forgotten problem of incontinence
}

\author{
David Oliver, consultant in geriatrics and acute general medicine
}

Berkshire

My local council has to find $£ 18 \mathrm{~m}$ ( $€ 22.3 \mathrm{~m}$; $\$ 24.7 \mathrm{~m})$ of savings by closing libraries, day centres, and public toilets. ${ }^{1}$ Residents have organised to keep one toilet open: they know its value. ${ }^{2}$ It's happening throughout the United Kingdom: even in my native Manchester, which the council says is "a great place to grow old,"3 only one public toilet remains. ${ }^{4}$

We report isolation and loneliness as having the most impact on wellbeing as we age. ${ }^{5}$ Fear of incontinence can be a major factor in trapping people in their own homes. ${ }^{6}$ And incontinence is a major trigger for stress among carers, prompting moves to care homes. $^{7}$

Urinary incontinence and lower urinary tract symptoms are a big deal but get low priority, partly because of our reluctance to discuss them. So I will. Storage symptoms include nocturia, increased daytime frequency, urgency, urge, and stress incontinence. Voiding symptoms include slow stream, straining, and dribbling. Post-micturition symptoms include sensation of incomplete bladder emptying and dribbling. ${ }^{8}$

Clinical audits have shown epic gaps in assessing, diagnosing, and treating incontinence, even in care homes and hospitals

These symptoms don't have the drama or visibility of a disabling stroke, severe cardiorespiratory limitation, or terminal cancer, but that makes them no less worthy of clinical attention. About one in three people over 60 experiences nocturia, and one in five has urgency. ${ }^{9}$ At least $15 \%$ of women over 60 report urinary incontinence at least monthly. ${ }^{10}$ Because of considerable under-reporting, the prevalence may be much higher. ${ }^{11}$

Although much urinary incontinence can't be cured, symptoms can be reduced and their impact on lives attenuated through a mixture of pharmacology, surgery, lifestyle changes, self management aids, appliances, and personal care. The evidence is set out in statutory guidelines, ${ }^{12}$ as are models for service delivery in NHS England commissioning toolkits. ${ }^{13}$

Yet clinical audits in England have shown epic gaps in assessing, diagnosing, and treating even severe and obvious incontinence. ${ }^{14}$ This occurs even in care homes and hospitals. And incontinence lies near the bottom among quality of care indicators reported by people over 50 in primary care. ${ }^{15} \mathrm{We}$ may cause or worsen incontinence in hospitals by unnecessarily catheterising or padding previously continent people, by pushing them to stay in bed and use bedpans, or sometimes inadvertently through drugs such as diuretics.

We could do more to raise awareness and make it easier for patients and carers to report incontinence. And, when they do seek help, they need informed assessment, diagnosis, and support.

The commissioning of health services should meet population and individual needs. Local public health plans should support wellbeing and independence. The government's response to the Francis report emphasised essential standards of care for people in hospital. ${ }^{16}$ These ambitions aren't always translated, as our failure to provide a decent offer for people living with urinary incontinence shows.

Competing interests: See www.bmj.com/about-bmj/freelancecontributors/david-oliver.

Provenance and peer review: Commissioned; not externally peer reviewed.

West Berkshire Council. Budget proposal for 2016-17—phase two. Mar 2016. http://info. westberks.gov.uk/index.aspx?articleid $=32040$.

2 Hyde N. Pangbourne toilet campaigners condemn parish council decision. Get Reading 2016 Jan 20. www.getreading.co.uk/news/reading-berkshire-news/pangbourne-toiletcampaigners-condemn-parish-10753990.

3 Manchester City Council. Summary: Manchester: a great place to grow older 2010-2020 www.manchester.gov.uk/downloads/download/3601/summary_manchester_a_great_ place to grow older 2010-2020.

4 BBC News. Public toilets "wiped out in parts of UK." 2016 May 31. www.bbc.co.uk/news/ uk-36405414.

5 Age UK. Loneliness and isolation evidence review. www.ageuk.org.uk/documents/en-gb/ for-professionals/evidence_review_loneliness_and_isolation.pdf?dtrk=true.

6 Help the Aged. Incontinence and older people. 2007. http://bit.ly/28WMTJ2.

7 Lievesley N, Crosby G, Bowman C; Bupa, Centre for Policy on Ageing. The changing role of care homes. Jan 2011. www.cpa.org.uk/information/reviews/ role of care homes. Jan 2011.
changingroleofcarehomes.pdf.

8 Rees J, Bultitude M, Challacombe B. The management of lower urinary tract symptoms in men. BMJ 2014;348:g3861. doi:10.1136/bmj.g3861 pmid:24963071.

9 Irwin DE, Milsom I, Hunskaar S, et al. Population-based survey of urinary incontinence, overactive bladder, and other lower urinary tract symptoms in five countries: results of the EPIC study. Eur Urol 2006;50:1306-14, discussion 1314-5. doi:10.1016/j.eururo.2006. 09.019 pmid: 17049716 .

10 Perry S, Shaw C, Assassa P, et al. Leicestershire MRC Incontinence Study Team. An epidemiological study to establish the prevalence of urinary symptoms and felt need in the community: the Leicestershire MRC Incontinence Study. J Public Health Med 2000;22:427-34. doi:10.1093/pubmed/22.3.427 pmid:11077920.

11 Wood LN, Anger JT. Urinary incontinence in women. BMJ 2014;349:g4531. doi:10.1136/ bmj.g4531 pmid:25225003. 
12 National Institute for Health and Care Excellence. Urinary incontinence in women overview. 2016. http://pathways.nice.org.uk/pathways/urinary-incontinence-in-women

13 NHS England. Excellence in continence care: practical guidance for commissioners, providers, health and social care staff and information for the public. 16 Nov 2015. https: //www.england.nhs.uk/commissioning/wp-content/uploads/sites/12/2015/11/EICC-guidancefinal-document.pdf.

14 Royal College of Physicians. National audit of continence care (NACC). 13 Aug 2015 https://www.rcplondon.ac.uk/projects/outputs/national-audit-continence-care-nacc.
15 Steel N, Bachmann M, Maisey S, et al. Self reported receipt of care consistent with 32 quality indicators: national population survey of adults aged 50 or more in England. 14 Aug 2008. www.bmj.com/content/337/bmj.a957.

16 Department of Health. Hard truths: the journey to putting patients first. Jan 2014. https:// www.gov.uk/government/uploads/system/uploads/attachment_data/file/270368/34658_ Cm_8777_Vol_1_accessible.pdf.

Published by the BMJ Publishing Group Limited. For permission to use (where not already granted under a licence) please go to http://group.bmj.com/group/rights-licensing/ permissions 